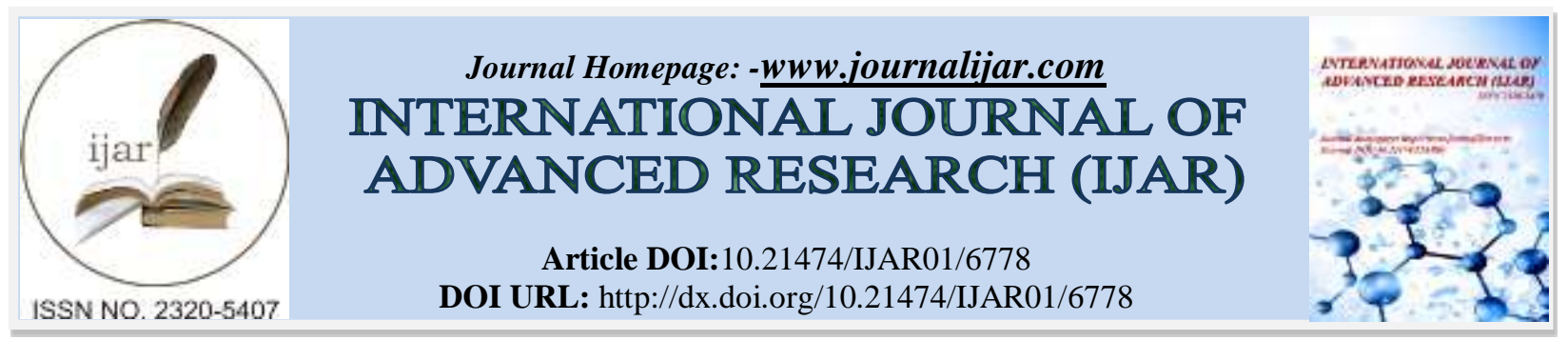

RESEARCH ARTICLE

\title{
LEGAL PROTECTION AGAINST WOMEN AS VICTIM IN DOMESTIC VIOLENCE IN PAPUA: A HUMAN RIGHTS PERSPECTIVE.
}

\author{
Efi Paulin Numberi*, Alma Manuputty, Slamet Sampurno Soewondo and Nurfaidah Said. \\ Graduate School, Faculty of Law, Hasanuddin University, Indonesia.
}

\section{Manuscript Info}

Manuscript History

Received: 18 January 2018

Final Accepted: 20 February 2018

Published: March 2018

Keywords:-

Human Rights, Legal Protection,

Domestic Violence, Women.

\section{Abstract}

The recognition, protection and human rights enforcement are legally guaranteed under various rules both in the constitution and in various organic laws. The research was conducted in Jayapura city, Papua Province, Indonesia. It is a normative and sociological research. The results show that the domestic violence against women is a family problem that difficult to expose to public, as a result of the publics' opinion and it can be resolved internally in a family. Patriarchal culture and misunderstanding to religion teachings and belief and the example of a boy against his fathers' character, as dominant factors causing the violence. Therefore, ideological approaches such as campaigns to stop various forms of gender inequality and by women to learn techniques how to stop violence. However, legal position for women is still weak, so the legal protection especially those concerning their natural rights has not yet received clear and firm recognition and protection in the constitution as a whole. Its implication is that there are still frequent cases that injure the dignity of women. The developing patriarchal culture in society influences the educational on the protection of women's rights. It is cause by the legal arrangement instrument, especially in Papua are still subject to patriarchal kinship system that discriminatory.

Copy Right, IJAR, 2018,. All rights reserved.

\section{Introduction:-}

The 1945 Constitution of the Republic of Indonesia as the supreme law affirms that Indonesia is a constitutional state that one of its purposes is to protect the whole nation and the blood of Indonesia. The essence of the protection of the whole nation and the blood of Indonesia is the protection of the glory as a whole human or in other words the protection of human dignity. Although in detail the problem of human dignity is not explained, but in principle, the meaning of human dignity is respect for oneself and self-esteem, which is related to the integrity and empowerment of physical and psychological. ${ }^{1}$ Therefore, the human dignity will be disadvantaged or at least will be disrupted by unfair actions based on personal traits or circumstances that are not related to the needs, capacities or characteristics of a person in the context of the abolition of sexual violence.

${ }^{1}$ Harkrisnowo, H. (2002). "Pancaila sebagai Paradigma Pembangunan Nasional Bidang Hukum dan Hak Asasi Manusia". in Kapita Selekta Pendidikan Pancasila untuk Mahasiswa. A Project for Improvement the Academic Officers at Directorate General of Higher Education, National Education Department, Jakarta. 
Human rights are human-owned rights by nature without exception. It provides a moral power to guarantee and protect the dignity of every person as Gods' creation. Substantially, human rights have been fought for human beings for centuries. In essence, the historical of human rights arises because the conscience of human about selfesteem, status and dignity as a result of the arbitrary actions of the rulers, colonizers, slavery, injustices and tyranny that almost struck all humanity.

In Indonesia alone, the recognition, protection and human rights enforcement are legally guaranteed under various rules both in the constitution and in various organic laws. The implementation of a constitutional state in accordance with Pancasila and the 1945 Constitution are absolutely requires a legislation that upholds human rights and guarantees all the rights of its citizens, equal position in front of the law and government and shall uphold such law and government with no exception. The reason why human rights should be upheld because every human being has inherent rights to him/her since birth, inalienable and inviolable by anyone. ${ }^{2}$ One way that State guarantees human rights is by establishing legislation that ensures law enforcement.

Inhuman or arbitrary discriminatory acts (violence) against women are part of the worlds' conflicts. The high level of violence against women prompted the United Nations Security Council to issue resolution No. 1325 and 1820 on the need for the prevention of gender-based violence especially in conflict areas and the importance of women's participation in peace efforts. Violence against women represents a human rights violation. It can occur anywhere (in public places, at work, family environment etc. It can be done by anyone (parents, brothers or sisters and etc) and may occur anytime (day and night). Recently, violence against women is very worrying for many people, especially among those who care about women. From the above statement can be concluded that basically the women's human rights really must be uphold and protected by the countries throughout the world.

The international concern for women's violence in addition to the resolutions issued by the United Nations also there are the Beijing Platform for Action which highlights the importance of State participation in protecting every woman from any gender-based violence and endangering the women's life. The rule of international law is known as pacta sunt servanda, an approved international treaty and it is mandatory. Countries of the world should not be excluded from such obligations rests on their national legal provisions. Rather, if national law reduces the implementation of an international treaty, the national law must be modified.

Internationally, the State participation in protecting every woman is regulated in the Convention on the Elimination of All Forms of Discrimination against Women (CEDAW) which states that countries as CEDAW' members shall amend national law to eliminate discrimination against women and to protect their rights. The national law of the Republic of Indonesia itself is derived from national law, customary law and religious law, among which there are still contradictions about the existence of the women's role. Act No. 7 of 1984 on ratification of respect for the women's rights as violence victims is stipulated in the Convention on the Elimination of All Forms of Discrimination against Women (CEDAW).

Since the ratification of the Convention on the Elimination of All Forms of Discrimination against Women $(C E D A W)$ in 1984, the Indonesian government has sought to eliminate discrimination against women, in particular through established or revised regulations. Another effort by the Indonesian government was to sign the Optional Protocol for CEDAW' Convention in February 2002, but the Indonesian government has not yet ratified the Optional Protocol. The Indonesia is also inconsistent and not wholly in implementing its commitments because there is still a gap between the written policy and its implementation. On the one hand, the State is good enough to make a legal breakthrough in favor of women, but on the other hand the State creates a number of rules at the national level, as well as in areas that discriminate against women.

In the structure of Indonesian society, and the world at large, there is a gap between status (rights and obligations) and the roles of men and women due to the Patriarchal system, which perpetuates male ${ }^{3}$ superiority, until 1994 there were women comprising teachers and activists of a number of women's NGOs established a "convention watch" working group. They are lecturer of Women Study, Postgraduate of Indonesia University. At that time the Women's

\footnotetext{
${ }^{2}$ Bytyqi, V. (2017). The State's Obligation to Protect the Individuals Lives from the Consequences of Domestic Violence. Hasanuddin Law Review, 3(1), 27-35. doi:http://dx.doi.org/10.20956/halrev.v3i1.897.

${ }^{3}$ L.M. Gandhi. Hukum Yang Mewujudkan kesetaraan Dan Keadilan Gender, Yayasan Pustaka Obor Indonesia, Jakarta, 2012. Pages 55-56
} 
Studies Center (WSC) was established in each university both public and private. The latest institution established through Presidential Decree No. 1 of 1998 is the National Commission on Anti-Violence against Women (the National Commission of Women) and has been renewed by Presidential Regulation No. 65 of 2005, the latest issuance of Act No. 23 of 2004 on the Elimination of Domestic Violence and it is abbreviated as PKDRT.

The National Commission on Anti-Violence against Women (the National Commission of Women) in performs its mission and vision creates conditions conducive to the elimination of all forms of violence against women and the upholding of women's human rights in Indonesia continues to receive input from various regions in Indonesia on the rise of violence against women. Although in the constitution, women's rights are protected in the 1945 Constitution and a number of laws and regulations but in reality the experience of violence that is still experienced by women, especially Papuan women up to now cannot be separated from the opaque history since the colonial period that so long struck the Papua region. Beginning from Patriarchal Indonesian cultural makes the position of women in an inferior state. This discriminatory culture has at least infected half of the human population. And unfortunately not many of us are aware to change the culture. Patriarchal is also makes women as second class citizens. Blame women for the violence they experience.

Generally, the domestic violence against women has been a long time. This causes domestic violence not easy to eliminate, it is rooted in a culture, misinterpretation of religious teachings or other reasons. It may even be that domestic violence has occurred as long as human civilization is simply unknown that it is a form of violence. ${ }^{4}$ In addition, there is an assumption that the wife is belonged to the husband, so that the husband can treat his wife at will. By such assumption, husband's attitude to his wife tends to make wife as object, not as subject or individual which have rights which should be respected. ${ }^{5}$ Domestic violence that was once considered a myth and a private matter has now become a fact in the household and the issue of domestic violence has become a public domain.

Patriarchal cultural as triggers of violence against women are also supported by the Resort Police' data of Jayapura indicate that in 2012 there were 79 cases of violence against women and children and increased to 164 cases in 2013. Furthermore, in 2014 decreased to 98 cases. However, since 2012 until 2014 cases of violence against children, namely sexual violence is the most prominent of violence in Papua and followed by domestic violence. Patriarchal and alcoholic cultures are allegedly as trigger of violence against women and children in this region. ${ }^{6}$

As described above is only a small part of the violence occurring in Papua that occurs in all aspects of life, which ultimately affects the disappearance of security and the strengthening of the belief that the enforcement and protection of human rights is the responsibility of the State. Special autonomy policy of Papua does not bring about improvements in the lives and welfare of most Papuan women, it is also acknowledged and contained in the explanation of Act No.21 of 2001 on Special Autonomy of Papua Province, which states that one of the reasons the province is granted special autonomy that governance and implementation of development in Papua Province has not fully fulfilled the sense of justice, has not fully enabled the welfare of the people, has not fully supported human rights in Papua Province, especially Papuan people. ${ }^{7}$

\section{Method of the Research:-}

The research was conducted in Jayapura city, Papua Province, Indonesia. It is a normative and sociological research. The normative analysis was to analyze the foundation of incident, the involvement of State in this case the government in providing protection to women in Papua Province. It uses legislation and case approaches. Both approaches are used to find and determine the basis of consideration or constructive (constructive teleological) from legal sources in the sense of historical, philosophical and juridical and determines the provisions that should be regulated in the legislation (rechtvorming). ${ }^{8}$

\footnotetext{
${ }_{5}^{4}$ Aroma Elimina Martha, Perempuan, Kekuasaan dan Hukum, UII Press, Jogjakarta, 2003, Page. 38.

5 Moerti Hadaiti Soeroso, Kekerasan Dalam Rumah Tangga, Dalam Perspektif Yuridis-Viktimologis, Sinar Grafika, Jakarta, 2010, Page. 63.

${ }^{6}$ Pers No: 63/Humas KPP-PA/07/2015

${ }^{7}$ Consideration Point f, Act No.21 of 2001 on Special Autonomy at http://legislasi.mahkamahagung.go.id

8 Mukti Fajar ND and Yulianto Achmad, Dualisme Penelitian Hukum, Fakultas Hukum Universitas Muhmmadiyah Yogyakarta, Yogyakarta, 2007, Page. 222.
} 


\section{Assessing the Humanitarian, Gender Equality and Gender Justice Principles in Papua:-}

As a philosophy, law serves as a guide to protecting human rights for common prosperity. Therefore, the principle of recognition and protection of human rights are the main principles that determine that a State is a constitutional State or intends to uphold the rule of law.

Gender is commonly used in linguistics to distinguish between different forms of women and men characteristics. It is then expanded in the social sciences to examine and to sees differences between women and men. Therefore, gender is a socio-cultural form that for every society has different forms between one society and the other. This is based on the prevailing values, norms and insights in the communities about the relationship between men and women. The system of values, norms, and stereotypes of men and women are seen as the main factors affecting the position and relationship of women and men in their environment and in their social structure. ${ }^{9}$

Generally, the concept of gender is associated with women because the community considers gender issues to apply only to women. The concept of gender is much opposed by men. Gender differences and patriarchal cultures generally impact on power conflicts between men and women where women are ultimately as victims.

So far, the cultural values raised are the values that support and preserve the patriarchal ideology with various forms and ways. The cultivation of patriarchal ideology has been done in two ways, that is, in a subtle way; it is socialized in education/parenting, and also in a coercion way with customary law sanctions or social sanctions. How way a patriarchal ideology ruled out, subordinate women can be prevented, as a counter-hegemony effort? This is homework to be solved jointly by the government and society to find the best solution to realize a better future of Indonesia.

Cultivates gender equality and justice values are a strategic move to make change. If the values of gender equality and justice are understood and practiced in family life, society, nation, and country then various injustices will be overcome. If various forms of injustice that constrain women's rights can be resolved, then the quality of life of women will increase which will inevitably affect the quality of life of children conceived, born and raised. This means that the increase in Indonesian human development index which is now still in 111 of 177 countries, cannot be separated from efforts to improve the quality of life of women. ${ }^{10}$

Observing the strong relationship between the empowerment of women in order to improve the quality of life of women with human development, then efforts to fight for must be done seriously and supported by all parties. The struggle to build a family, society and a nation in gender equality should be undertaken as a shared movement, as part of the cultural movement to bring about a better Indonesian society. The social values and norms of Papuan community have generally defined the characteristics of men and women (gender) based on their cultural values, including what roles men and women should perform, and what resources reachable and controlled by men and women.

In ancient times, the traditional roles of men and women were said to be quite balanced. Both men and women have equal responsibility. Men are responsible for political affairs (war, negotiating with enemies, holding peace), keeping the village, guarding women in the garden, taking care of traditional ceremonies, preparing new fields, and searching for firewood, hunting, trading. Women are responsible for feeding in the garden, preparing food for the family, taking care of pigs, taking care of children and domestic work and helping men in preparing traditional ceremonies.

Gender differences do not really matter as long as they do not give rise to gender inequalities. However, the question arises that gender differences have given birth to various injustices. Although men do not rule out the possibility of becoming victims of gender inequality, but women still occupy the highest position as victims of gender injustice.

Gender disparity makes women more vulnerable to crime victims. When women are really as crime victims, then the crime reinforces the imbalance of gender power between men and women. This is an analysis of Brownmiller about

\footnotetext{
${ }^{9}$ Muhadar Sulaiman. Kekerasan Terhadap Perempuan. PT. Rafika Aditama. Bandung. 2010 Page. 42.

${ }^{10}$ Isra, S., Ferdi, F., \& Tegnan, H. (2017). Rule of Law and Human Rights Challenges in South East Asia: A Case Study of Legal Pluralism in Indonesia. Hasanuddin Law Review, 3(2), 117-140.
} 
relationship between gender power disparity and female victimization. The relationship between violence and gender power imbalances is in the form of a growing spiral. ${ }^{11}$

In other words, the violent crime affirms that women have no effective authority. According to Kepala Badan Pemberdayaan Perempuan dan Perlindungan Anak (BPPPA) of Jayapura city, Betty Puy said that violence against women and children, as well as domestic violence in Jayapura city in year 2015 is 86 cases, while in 2016 is 3 cases. Of the three cases, two cases have been entered into the District Court of Class IA Jayapura, since January 2016 ago. Hence, there is an increase in cases of domestic violence that mostly occurs in women and children, said Betty when met in her office at Mayor Office of Jayapura, Jayapura city, Wednesday (17/2). ${ }^{12}$

The Report of Human Development and Gender Equality of Papua Province in 2012 issued by Regional Development Planning Agency of Papua Province in collaboration with UNDP and involving intensive consultations with representatives of government agencies, the Papuan People's Assembly, non-governmental organizations and individuals concerned with gender issues in Papua Province and National level shows the Life Expectancy Rate (LER) of Papuan population is $72.91 \%$, where LER of female is 74 while male is 70.95 . Based on this figures that LER of Papuan female both at the provincial and district that Papuan Gender Development Index Papua is the lowest at the national level. The poverty that exists in Papua is not only a matter of lagging, location and geographical situation and also gender-based gaps and discrimination. ${ }^{13}$ Gender-based violence is a natural extension of the patriarchal value order that views women as male subordinate and gives men the right to control women, therefore men put themselves as dominant.

Discussing the Patriarchal culture is inseparable from the differences in gender roles, where Papuan women are accustomed to being second position or not even getting the same place as Papuan men. In Papua culture, women are accustomed to working outside, looking for food for their families, working in the fields, seeking for fines if their husbands commit abuses. The Papuan men are only working to war, to negotiate the peace of war and to open the fields. This is what causes inequality or injustice. Women look very disadvantaged, if there is a problem that the victims are women. Women are also often used as objects of anger from a Papuan man if his wishes are not met.

The men in Papua are very angry and sometimes easy to beat their wives. They do not seem to realize that anger and even outrage of anger in the form of physical and psychological torture is a very harmful act of self even very harmful to the wife who should be in love, and protected.

Elimination of domestic violence is a guarantee provided by the State to prevent domestic violence, and to prosecute such violence perpetrators and to protect victims of domestic violence. People in Papua embrace Patriarchy culture. As stated by the Minister of Women Empowerment and Child Protection, Yohana Susana Yembise that "Patriarchal culture places women in the shadows of the men." Freedom of women in Papua depends on men. If a woman begins to have ability or intelligence, the tribe will try to prevent the woman from learning and making performance.

Patriarchal culture is also very visible in marriage life in Papuan peoples. In the marriage, frequently the parents ask dowries in large numbers to the man groom, even worth hundreds of millions of dollars. So, the Papuan men assume that it is reasonable for them to apply arbitrarily to their wives, since they think they have bought enough to marry a Papuan woman. This is factor that triggers the occurrence of cases of violence against wives whose escalation is quite increased. Even domestic violence that occurred in Papua has the highest ranking in Indonesia.

In addition to the difference of gender, women are always charged with responsibility for productive and reproductive work, in support their husbands to perform social- and productive roles which are supposedly done by men (husbands) but in reality are done by women who spend their entire day in the field, for food and nutritional intake, women always get discrimination with much less food and nutritional portion than men, whereas their energy has been depleted, resulting in worsening health conditions of women, due to chronic malnutrition.

And also, many Papuan women became sexual objects by a husband who has had free-sex to anyone, a husband susceptible to other sexually transmitted diseases should transmit also to his wife, because as if it has become a

11 Reumi, F., Yunus, A., \& Irwansyah. (2015). Recognition of the Customary Court: A Review of Decentralization in Papua as Special Autonomy. Journal of Research in Humanities and Social Science 3 (7), 57-69

${ }^{12}$ Daily Kabar Papua.co Member of Kabar Newswork, 29 August 2017

${ }^{13}$ Report Paper: Pembangunan Manusia dan Kesetaraan Gender Provinsi Papua 2012 Published on Dec 8, 2015 
natural phenomenon, free sex is common in Papua, this is what causes the development of sexually transmitted diseases that led to the oppression of women. Also, not yet family planning and abortion problems in Papua that result in the dominance of the ego of a Papuan man who is as willing as he pleases, regardless of gender role and respect for Papuan women properly and the image of violence against the wife takes place.

The inland of Indonesia, in Asmat women, for example, Dewi Linggasari found out how they received physical, economic, and psychological violence from their husbands. They must meet the logistical needs of husbands by looking for sago in the forest that must be reached by boat for 2 hours. They manage and cultivate the sago while taking care of the child. Other domestic work such as washing clothes and gardening also they do without the help of her husband, taking water in the river for bathing. If the tasks are not performed properly, the husband feels entitled to physical violence. Not to polygamy by husband really adds to the suffering of Asmat women. ${ }^{14}$

Concerns the forms of violence that occurred in the Patriarchal culture based on the results of interviews with one of the Head of Tribe in Wamena Jayawijaya named Felius Wetipo that in the culture of Dani ethnic, where the author tries to arise a topic of violence against women that is cut finger or called Iki Palek. Iki Palek or cut finger are performed in the event of grief to show a sense of love to a deceased person where Dani women who has to experience pain for one finger is sacrificed.

The woman is always considered "the second." This is in line with the theory of nature. ${ }^{15}$ The theory of nature is developed by Functionalist and Marxist ideals. In Functionalist theory, the division of roles between men and women in society is essentially sexual division. Functionalist understands more about the role of women in the family. For Functionalist understanding, the function of family are always the same, namely sexual intercourse that gets the legalization of society, the functions of economic, development of offspring, and educational for children born in the family. ${ }^{16}$

The division of sexual roles does allow each party (men and women) to benefit from it. However, this makes men more able to use and make it as an opportunity to develop his power. In Dani peoples, Woman has dual function, where Dani's women have to function to take care of husband and children and also have to preserve the agriculture (gardening) and livestock (pig). It indicate that Patriarchy cultural as a trigger of domestic violence in Papua (Table $1)$.

Table 1:- Factor of Patriarchy cultural as cause violence against women

\begin{tabular}{|l|l|l|l|}
\hline No. & Response & Frequency & Percentage (\%) \\
\hline 1 & Very influential & 6 & 46.16 \\
\hline 2 & Influential & 5 & 38.46 \\
\hline 3 & Less influential & 1 & 7.69 \\
\hline 4 & No influential & 1 & 7.69 \\
\hline & Total & 13 & 100 \\
\hline
\end{tabular}

Source: Secondary data, 2017

Respondents in response to these factors are 4 people of peoples, 3 Police Investigator of Jayapura, 3 Prosecutor at High Attorney of Jayapura, 3 judges in District Court IA of Jayapura that all amounted to 13 respondents. Domestic violence against Papuan women is caused by the dominance of patriarchal culture which is also followed by weakness and obstacles faced by law enforcement officers.

In outline, the women participation rate in crime is small compared to the men participation rate. Currently, many women are more accepted in public positions. For example, in the field of law, police, and society and even in the field of politics that has been established rules of legislation. However, the frequency or potential of women as violence victims such as rape, domestic violence, and incest is still very worrying. There is a need elaboration about the law power that reinforces a system of culture that hates or demeans women (misogynist cultural system).

${ }^{14}$ Hadaiti Soeroso, 2010. Kekerasan Dalam Rumah Tangga, Dalam Perspektif Yuridis-Viktimologis, Sinar Grafika, Jakarta.

15 Arofa, E., Yunus, A., Sofyan, A., \& Borahima, A. (2015). Corporate Criminal Liability for Corruption Offences in Indonesian Criminal Justice System. International Journal of Advanced Research, 3(8), 246-250. p. 15

${ }^{16}$ Andrey Sujadmoko, 2005. Tanggung Jawab Negara Atas Pelanggaran Berat HAM , Jakarta: Grasindo, p 23 


\section{The Concept of Elimination of Domestic Violence against Women in Papua:-}

Patriarchal culture and misunderstanding about religion teachings and belief and the imitation of a boy against his father's character as dominant factors causing the violence. Therefore, ideological approaches such as campaigns to stop various forms of gender inequality and studying techniques by women in stopping violence in legal protection of women as domestic violence victim in their homes.

The problem of domestic violence as experienced by Papuan Women embrace Patriarchal culture. As stated by the Minister of Women Empowerment and Child Protection, Yohana Susana Yembise, Patriarchal culture places women in the shadows of the men." Freedom of women in Papua depends on men. If a woman begins to have ability or intelligence, the tribe will try to prevent the woman from learning and making performance. It is also very visible in marriage life in Papuan peoples. In the marriage, frequently the parents ask dowries in large numbers to the man groom, even worth hundreds of millions of dollars. So, the Papuan men assume that it is reasonable for them to apply arbitrarily to their wives, since they think they have bought enough to marry a Papuan woman. This is factor that triggers the occurrence of cases of violence against wives whose escalation is quite increased. Even domestic violence that occurred in Papua has the highest ranking in Indonesia.

The description can be seen from the results of research at the Resort Police of Jayapura city concerning criminal acts of the protection of women and children at Resort Police of Jayapura city in period 2016 to October 2017 as showed in Table 2.

Table 2:- Recapitulation of case handling of domestic violence

\begin{tabular}{|l|l|l|l|}
\hline No & Year & Total Case & Remark \\
\hline 1. & 2016 & 45 cases & Data were obtained from the General Crime of the High Attorney and 10 \\
\hline 2. & 2017 & 31 case & District Attorney in Papua \\
\hline
\end{tabular}

Source: Women and Child Protection Unit at Resort Police of Jayapura city, 2017 (edited).

Based on the result of research, the number of domestic violence cases in the Resort Police of Jayapura city indicates that from 2016 to 2017 has increased significantly. In order to prevent, protect victims and take action against perpetrators of domestic violence, the State and society shall exercise the protection, enforcement and prosecution of perpetrators in accordance with the Pancasila philosophy and the 1945 Constitution of the State of the Republic of Indonesia. States view that all forms of violence, especially domestic violence is a violation of human rights and crimes against human dignity and form of discrimination.

The protection of victims in the criminal justice process is inseparable from the protection of the victims according to the prevailing legal provisions. In positive criminal law that applied today, the protection of more victims is "abstract protection" or "indirect protection", meaning that the existence of various formulations of criminal offenses in legislation so far there is essentially a protection in abstracto indirectly against various legal interests and the rights of victims. ${ }^{17}$

The government has established various strategies for the protection of the dignity of women and children as human beings who are considered weak and vulnerable to violence. This strategy is a tool to improve the quality of life of women so that they can become citizens who play a role in life.

The regional government of Papua Province through Act No. 21 of 2001 on Special Autonomy for Papua Province has not been able to actually provide protection for Papuan women and fulfill the sense of justice who is still living in the chain of patriarchal cultural violence. Patriarchal system is a system that favors male domination. According to radical feminist ideas, this is the cause of gender inequality and adversely affects the reality of women's lives.

Increases mainly caused by men in the family. Women as victims also experience non-sexual violence such as: murder, attempted murder, torture, arbitrary detention, displacement, destruction and property confiscation. In addition, the domestic violence, women as vulnerable to violence experience forms of physical, psychological and sexual violence in the form of: polygamy/ cheating, torture, economic neglect, marital rape, psychic violence, restriction of space and forced marriage.

${ }^{17}$ Barda Nawawi Arief, 1998, Beberapa Aspek Kebijakan Penegakan dan Pengembangan Hukum Pidana, Bandung : Citra Aditya Bakti, Pages. 53 - 54 
The result of survey on violence against children and women as conducted by the Central Bureau of Statistics in 2016 found that the number of violence against women in Papua was the highest in Indonesia. According to the survey, violence in Papua reached $13.62 \%$ of nationally reported cases. Of these figures, oppression is the highest form of violence experienced by women in Papua, with a percentage of $70.3 \%{ }^{18}$

It can be said that the change of values and behavior among men is inseparable from the continuous fund flow of Special Autonomy since 2001, causing women to be subjected to violence. Lembaga Pengkajian dan Pemberdayaan Perempuan dan Anak Papua (LP3AP) in cooperation with Badan Pemberdayaan Perempuan Papua (BP3), provides assistance and crisis centers for women as violence victims. The data they collected showed that the main perpetrators of violence were women themselves, who were mostly local officials or civil servants. The large fund of Special Autonomy is implicated to the high rate of drinking behavior among men and the increasing tendency of polygamy or infidelity. ${ }^{19}$

The phenomenon is very dominant in Jayapura city as an urban area that became the stopover of many humans who entered into Papua. According to the report of Central Bureau of Statistics Papua in 2014 that total population of Papua is 3.091.047, spread over 29 districts/cities where the largest population in Jayapura city consists of 275.694.

The aspect of philosophical relating to women as who vulnerable to the violence is the basis for thinking about the need for legal instruments that regulate the fulfillment of the women' rights who as violence victims and human rights in a dignified and fair manner and to regulate the impact of acts of violence and human rights violations against women that has been happening in Papua Province.

Until now, the territorial security approach tends to have a negative impact on the civilian population, including women and children. No exception for Papuan women. A number of Papuan women have experienced various forms of gender-based violence over the past four decades, particularly in the context of the security approach practiced in Papua. Nevertheless, the violence has forged Papuan women to become clearer about their problems and to survive in uncertain conditions.

Also, social change in Papua resulted in a shift in the pattern of relations between men and women. In this context, the fact of violence against women is not a matter of concern in custom. In the context of cultural, discrimination against women in the Papuan occurs in the domestic sphere, such as the division of labor, the pattern of parenting, the distribution of property rights and inheritance and decision-making in the family.

As result of documentation can be drawn a conclusion that women in Papua Province faced with conditions that make their position squeezed and as main target of violence. Etymologically, the State or Government, both central and local governments are obliged to make various efforts to protect women with the rights inherent in themselves as human beings. This is because women as human beings are creatures of God who since birth has the basic rights inherent as a human (it called human right). Without the basic rights inherent in women, they cannot fulfill their dignity as human beings who have a high degree of dignity, mind and independent initiative in themselves.

Furthermore, it is the government and State's task and responsibility and to create opportunities and conditions conducive to fulfill their rights. This includes efforts to eliminate all forms of threat, violence, discrimination, stereotypes, intimidation and marginalization. It must be admitted that up to now efforts to promote, fulfill, protect and uphold the women's human rights are still very weak and slow progress. On the other hand, violence, discrimination and women rights violation occur in almost all aspects of life and are increasing in number and variety. In fact, women as human beings are potentials that should be protected and developed for the benefit of the people themselves, whether as individuals, families, communities, and the State.

\section{Conclusion:-}

Domestic violence against women is a family problem that difficult to expose to public, as a result of the publics' opinion that the problem is a natural and it can be resolved internally in a family. Patriarchal culture and misunderstanding to religion teachings and belief and the example of a boy against his fathers' character, as dominant factors

${ }^{18}$ Source: Koran Tempo, 12 December 2007.

${ }^{19}$ Selfiana Senggenafa, Director of LP3AP, LP3AP Every year receive many violence cases. In 2007, there are 87 case and complaint, in which 74\% of amount is violence against women, especially in domestic violence, September 2008. 
causing the violence. Therefore, ideological approaches such as campaigns to stop various forms of gender inequality and by women to learn techniques how to stop violence.

Legal position for women is still weak, so the legal protection especially those concerning their natural rights has not yet received clear and firm recognition and protection in the constitution as a whole. Its implication is that there are still frequent cases that injure the dignity of women. The developing patriarchal culture in society influences the educational on the protection of women's rights. It is cause by the legal arrangement instrument, especially in Papua are still subject to patriarchal kinship system that discriminatory.

\section{References:-}

1. Andrey Sujadmoko. Tanggung Jawab Negara Atas Pelanggaran Berat HAM, Jakarta: Grasindo, 2005.

2. Aroma Elimina Martha, Perempuan, Kekuasaan dan Hukum, UII Press, Jogjakarta, 2003.

3. Bytyqi, V. (2017). The State's Obligation to Protect the Individuals Lives from the Consequences of Domestic Violence. Hasanuddin Law Review, 3(1), 27-35.

4. Daily Kabar Papua.co Member of Kabar Newswork, 29 August 2017.

5. Hadaiti Soeroso. Kekerasan Dalam Rumah Tangga, Dalam Perspektif Yuridis-Viktimologis, Sinar Grafika, Jakarta, 2010.

6. Harkrisnowo, H. 2002. "Pancaila sebagai Paradigma Pembangunan Nasional Bidang Hukum dan Hak Asasi Manusia". in Kapita Selekta Pendidikan Pancasila untuk Mahasiswa. A Project for Improvement the Academic Officers at Directorate General of Higher Education, National Education Department, Jakarta.

7. Iqrak Sulhin. Kekerasan dan Kultur Patriarki. A Lecturer of Criminology Department of UI, For Phenology, Theoretical Criminology, and Criminal Policies. Kompas News.

8. Isra, S., Ferdi, F., \& Tegnan, H. (2017). Rule of Law and Human Rights Challenges in South East Asia: A Case Study of Legal Pluralism in Indonesia. Hasanuddin Law Review, 3(2), 117-140.

9. Koran Tempo, 12 December 2007.

10. L.M. Gandhi. Hukum Yang Mewujudkan kesetaraan Dan Keadilan Gender, Yayasan Pustaka Obor Indonesia, Jakarta, 2012.

11. Mardjono Reksodiputro, Hak Asasi Manusia Dalam Sistem Peradilan Pidana, Pusat Pelayanan Keadilan dan Pengabdian Hukum (d/h Lembaga Kriminologi) Universitas Indonesia, Jakarta, 1997.

12. Moerti Hadaiti Soeroso, Kekerasan Dalam Rumah Tangga, Dalam Perspektif Yuridis-Viktimologis, Sinar Grafika, Jakarta, 2010.

13. Muhadar Sulaiman. Kekerasan Terhadap Perempuan. PT. Rafika Aditama. Bandung. 2010.

14. Mukti Fajar ND and Yulianto Achmad, Dualisme Penelitian Hukum, Fakultas Hukum Universitas Muhmmadiyah Yogyakarta, Yogyakarta, 2007.

15. Report Paper: Pembangunan Manusia dan Kesetaraan Gender Provinsi Papua 2012 Published on Dec 8, 2015.

16. Reumi, F., Yunus, A., \& Irwansyah. (2015). Recognition of the Customary Court: A Review of Decentralization in Papua as Special Autonomy. Journal of Research in Humanities and Social Science 3 (7), 57-69. 